\title{
The Influencing Factors of Dropout and Persistence of Central European Hungarian Minorities in Higher Educational Institutions
}

\author{
Zsuzsanna Sütö ${ }^{1}$ \\ Recommended citation: \\ Sütö, Zs. (2020). The Influencing Factors of Dropout and Persistence of Central European Hungarian Minorities in Higher \\ Educational Institutions. Central European Journal of Educational Research, 2(3), 90-98. https://doi.org/10.37441/ \\ CEJER/2020/2/3/8282
}

\begin{abstract}
The statistics show that minority Hungarians' education and participation in higher education, lags far behind the majority of society in Central Europe. Furthermore, we also know that the smaller the community, the more educated they are. The explanation for this could be, those who are less educated are more prone to assimilate. As a result, the existential question from these minority groups comes down to the growth of their level of education, a condition of which is university students' acquisition of diplomas. Those factors deserve more scrutiny, in their identification, that increase the chances of getting a diploma. The goal of our study is (1) to identify the students who are persistent and at risk of dropping out, (2) to define the risk factors, and (3) at the same time to uncover the protective/ supporting factors as well. The theoretical background for our research was constituted by the institutional integrational model. The database used for this study contains data collected during a survey of Hungarian students from four different countries in Central Europe (IESA 2015, N= 2017). We found from our research that though the effect of intergenerational connections among students at Central European minority schools proved significant, the effect of place of residence, of settlement type, and of relationships within the family was even stronger.
\end{abstract}

Keywords: persistence, dropout, minority Hungarian higher education

\section{Introduction}

The statistics still show that minority Hungarians' education and participation in higher education, lags far behind the majority of society in Central Europe. Following 2010, the regional average of across-the-border, active, Hungarian-speaking institutions was that more than three fourths of students were first-gen intellectuals (Pusztai \& Márkus, 2019). Literature puts them among the non-traditional students, for their appearance in higher education has drawn institutions into a new situation, since, for these students, the intellectual and gregarious environment falls far from such institutions, the classical collision of identifying with the middle class and the academic world. For this reason, there is a greater chance they will fail, thus edging them closer to dropout (Pusztai, 2011; Altbach, 2009). This puts a greater weight of responsibility on institutions and communities as the construction of a sort of institutional safety net 'round the students also becomes their job. In a broader sense, the minority communities' social structure and mobility features depend on the success or failure of this process. As a result, the examination of the phenomenon of drop-out and the expounding of the complex correlation between the latter, the unique aspects of minorities, its possible regions or reasons deserves the special attention of researchers and scientists. The goal of the current study is the identification of the minority students at risk of abandoning their studies and of those who are striving on, the definition of drop-out's individual and institutional risk factors, and, parallel with this, the determination of the components

\footnotetext{
${ }^{1}$ Centre for Social Sciences Institute for Minority Studies Hungarian Academy of Sciences Centre of Excellence; Suto.Zsuzsanna@tk.mta.hu
} 
that protect them from the latter. In other words, it is to identify the interaction between students' attitudinal, activity structures and the institutional environment.

In the last several years the evaluation of higher educational performance has grown to be at the center of foreign and domestic attention. Most often international studies have looked at the issue from a negative angle, blaming students' quitting their academic careers on lack of success, a.k.a failure - posing a growing complication for the education systems of developed, western societies as well. Student drop-out is a problem in which everyone in higher education is affected on multiple levels. This kind of evaluation of cross-border, minority Hungarian-language higher education is lacking from the study repertoire. The research carried out, by the Debrecen University's Center for Higher Education Research and Development in recent years on the fringe of the Central European region, have begun to focus on measuring the region's university students' performance, among them that of minority groups as well (Pusztai \& Szigeti, 2017; Pusztai et al., 2015a). One of the most important premises of these studies is, due to the higher education students' own social and multicultural composition, the universal performance indicators used in international studies cannot be adapted without criticism. For example, it came to light that students' religious, denominational standing carries great weight when it comes to minority students' performance indicator (Márkus, 2015). In the tests run by Pusztai (2018) and her colleagues, they placed emphasis on the discovery and naming of risk and protective factors predicting higher education drop-out. Their results prove that the students who left their studies incomplete were less committed regarding the completion of their student career, furthermore they valued their own prospects of getting a diploma in a less positive light. The ratios of institutional drop-out are also in harmony with the ratio of persistent and less persistent students. In addition, said results also speak of the fact that we can look on the phenomenon of persistence as that which minimalizes the chances of drop-out. They handle the processes of students' institutional socialization and the level of their institutional embeddedness as the central question in their examinations. In fact, their experience was that the more frequently-occurring and widespread institutional relationship network is able to mitigate social status' determinate effects on the successful acquisition of a degree (Pusztai, 2018).

The theoretical background for our research was constituted by the institutional integrational model (Tinto, 1975; Pascarella \& Terenzini, 1980). The model starts from the interactions between the individual and the higher education facility, and draws correlation between the measure of students' integration into the institution and the success of their careers. The theory states, the unsatisfactory institutional socialization measures are also to blame for students' lack of success. In other words, the developed labyrinth of relationships, the amount of and multiplexity of social and academic interaction within the institution all play major roles in a student's performance. The more a student becomes a part of the life of a higher education institution (takes part in university programs, does extracurricular activities, etc.) and takes part in campus community (forms as many connections as possible), the higher the chance of getting a diploma, and lower the chance of drop-out. At the same time, this also attributes great significance to his/ her socio-economic background in successful institution socialization processes (Tinto, 1975; Pascarella \& Terenzini, 1980).

\section{Research design and Methods}

For the analysis, we used the database of the Institutional Effects on Student Achievement's (IESA) international students enrolled in the fall/winter of 2014-2015 (Pusztai et al., 2016). We inspected the data of 1,739 Hungarian minority students from thirteen higher education institutions located in various regions of four Central European countries (Pusztai et al., 2016). In our comparative analysis, we contrasted the data of students from the faculties of Hungarian-language higher educational institutions in Romania, the Ukraine, Serbia, and Slovakia. In our database, we strived to represent the institutions' full-time, state-funded students who we examined. The definition of the sampling framework was done based on the institutions' data service. The students were searched for by group in university/ college courses. The random selection of these groups ensured that prevalence of randominity.

Students' persistence, according to Pusztai $(2011,2014)$ was measured as an indicator calculated with a 9-item, four-degree Likert scale. Part of the questions were concerned with the measure of commitment to completing current studies:

„The studies that I'm doing will be useful to me in my professional carrier”; „I've very devoted to finishing my schooling"; I would like to reach even higher educational achievement"; I will do everything so that I might participate in lectures, seminars, and tutorial classes". The other half of the questions, however, calculated students' self-efficacy: „I am able to pay attention in class”; „Usually I participate in lectures and 
seminars"; „I am able to prepare for exams” The reliability of persistence scales defined in this way is high, its Cronbach-alpha value being 0.921. On the nine variables' values we finished a main component analysis, the explained variance coming out to 61.4. We converted the main components' weights on a scale from 0 to 100 , where 0 shows the least persistence value, 100 showing the greatest persistence value.

The analysis' descriptive variables, along with its unavoidable social and socio-cultural indicators were country, gender, parents' degree of education, residence at the age of 14 , objective, subjective and relative financial status and social capital within the family. At the time of the objective financial status' determination, we in usual fashion asked students to identify those consumers goods out of nine goods listed which were in their possession. We considered it necessary in every way to involve in the analysis other economic situation indicators. When we defined the subjective financial situation, we asked respondents to measure their current situation appropriately, whether or not they have money problems, and if so to what extent. After all, when the financial position was established, we were forced to relate back to the situations of past years and to other groups' statuses. We must consider the following an important question: who do students consider members of their reference group? In answering this question, the survey's relative indicator for measuring economic status came in handy, when we asked respondents to compare their economic situation to that of other families living in their countries. Among educational sociologists there is no dispute about the fact that individual higher educational aspirations are formed by not only social and cultural factors but by resources on the individual level as well (Pusztai, 2009; Pusztai \& Verdes, 2002). Cultural capital within the family appears as such a resource, which according to Pusztai $(2009,2004)$ is able to override the family's cultural capital. On the survey, the amount of capital within the family was measured by frequency of various common activities such as, conversation (about different topics from public life, about studies, about friends), planning shared programs, or doing housework together, etc.

Upon entrance into higher education, experiences serve as resources, thus, in our analysis we included the high school type and its caretaker, what's more participation in private classes was also included.

The next step in the analysis was where we compared the persistence indicator with the various indicators of institutional effect that is to say, with the indicators of residence during the semester (dormitory) and of students' institutional embeddedness, the samples of integrational relationship networks within the institution, and the measure of group membership. Educational research holds the following to be a key question: In what areas and among which social groups do students move during the university years? Earlier tests revealed that there are multitudes of differences between the commuting student and the dormitory-dwelling student. For example, among those pupils in the dorm, dropout is much less, they're more contented with their institutions, they more often plan to continue their studies, or they more actively take part in extracurricular activities (Pusztai, 2015b; Astin, 1993; Tinto, 1975; Pascarella \& Terenzini, 1980).

In the final prong of our analysis, we compared the chance of one becoming persistent with the total effect of the different variables, using a control analysis, and defined the estimates of some of those variables' expected values. We, in three steps, drew the variable groups into the logistical regression model. First the social background indicators, next the attributes of earlier courses of study, and finally the variables of the institutional effect indicator were added to the model.

\section{Results}

One of the defining experiences of our previous analyses is that we cannot view the beyond-the-border Hungarian student body as one community based simply on the amount of students with minority status, and that in future analyses it would be worth it, at the very least, to include regional level data. It is not the aim of the current work to measure, or to qualify, the operations of the various institutions, thus we, in our analyses, compared each country.

First of all, we examined the judgment of the combined persistence indicators as items within student circles and statistically found many differences. Namely the students from the Vojvodina and Transylvania/ the Partium agree with the statement regarding their measure of dedication to finish their current studies, this same motivation being of little significance to students from Transcarpathia and the Hungarian Highlands (modern-day Slovakia). In the acceptance of the later persistence indicator statements pertaining to self-efficacy, the students of the Vojvodina again take the lead, with the self-regulating and self-organizing abilities we detected in the Hungarian Highland (Slovakia) students being of the littlest measure. The differences from country to country are significant here as well. 
In the next phase of our research, we tested students' demographical and sociocultural attributes' connections to persistence. Using a variance analysis, we identified which variables, from country to country and on an individual level, most support persistence. Based on the average count of the persistence indicator, the highest number was reached by Serbian (76.35) and Romanian (70.53) students. Below the sample average (67.36) were found Ukrainian (64.95) and Slovakian (61.13) students. The differences in the average point numbers were also statistically measurable. Student persistence was most reinforcing, the individual level attributes also varied from country to country. In Romania, the women are the ones who are at more of an advantage. In Ukraine, diploma-wielding fathers were among those examined variables who most supported the formation of persistence, while in Slovakia, economic status measured by the objective financial situation was more advantageous. In Serbia however, the social capital within the family alone added considerably to students' success. We must at this point highlight the significance of social capital within the family, after all, this was the only variable which in every country best displayed relationship with the odds of persistence formation, overrides the forces of less favorable family cultural and economic capital. It is easy to see that the minority students gather their study resources from family environments. Furthermore, 'tis worth mentioning the economic situation indicators' varying powers of motivation. While the economic situations deemed less fortunate drive students from Transcarpathia in their advanced - level studies, the more fortunate or advantageous situations aid those in the Highland. However, such fundamental status factors like parental level of education, the settlement type in which they live don't reveal connections with the phenomenon. 
Table 1. A diagram of individual attributes connected to above average increase in a student's persistence The level of connection significance: $* * *=0,000 ; * *<0,03 ; *<0,05$

\begin{tabular}{|c|c|c|c|c|c|}
\hline \multirow{2}{*}{\multicolumn{2}{|c|}{ Individual Attributes }} & \multicolumn{4}{|c|}{$\begin{array}{l}\text { Main component of Persistence } \\
\text { (Points on a 0-100 degree scale) }\end{array}$} \\
\hline & & $\begin{array}{l}\text { Romania } \\
(\mathrm{N}=213)\end{array}$ & $\begin{array}{l}\text { Ukraine } \\
(\mathrm{N}=129)\end{array}$ & $\begin{array}{c}\text { Slovakia } \\
(\mathrm{N}=65)\end{array}$ & $\begin{array}{c}\text { Serbia } \\
(\mathrm{N}=62)\end{array}$ \\
\hline No & $\begin{array}{l}\text { female } \\
\text { male }\end{array}$ & $\begin{array}{l}72,59 * * * \\
63.25 * * *\end{array}$ & $\begin{array}{l}67,63 \\
65.76\end{array}$ & $\begin{array}{l}63,09 \\
58.83\end{array}$ & $\begin{array}{l}76,97 \\
62.60\end{array}$ \\
\hline \multirow{3}{*}{$\begin{array}{c}\text { Birth father's/foster father's } \\
\text { educational level }\end{array}$} & beginner & 71.72 & $60.01 *$ & 64.17 & 83.66 \\
\hline & intermediate & 71.56 & $68.27 *$ & 63.04 & 72.47 \\
\hline & advanced & 69.47 & $71.49 *$ & 66.29 & 78.49 \\
\hline \multirow{3}{*}{$\begin{array}{l}\text { Birth mother's/foster mother's } \\
\text { educational level }\end{array}$} & beginner & 71.62 & 60.73 & 68.35 & 81.64 \\
\hline & intermediate & 72.39 & 68.69 & 60.55 & 76.51 \\
\hline & advanced & 67.52 & 69.25 & 65.09 & 69.09 \\
\hline \multirow[b]{2}{*}{ Place of residence at age 14} & village & 73.34 & 68.85 & 62.11 & 77.50 \\
\hline & city & 70.02 & 64.05 & 64.19 & 74.82 \\
\hline \multirow{2}{*}{ Objektive financial situation } & below mean & 70.23 & 62.68 & $52.10 * *$ & 80.18 \\
\hline & above mean & 70.75 & 67.65 & $64.49 * *$ & 74.15 \\
\hline \multirow{2}{*}{ Subjektive financial situation } & below mean & 72.06 & 68.32 & 56.13 & 66,98 \\
\hline & above mean & 71.85 & 68.16 & 64.16 & 78.79 \\
\hline \multirow{2}{*}{ Relative financial situation } & below mean & 72.27 & 66.96 & 63.29 & 78.04 \\
\hline & above mean & 70.91 & 68.14 & 63.39 & 72.31 \\
\hline \multirow[b]{2}{*}{$\begin{array}{l}\text { Social capital within the } \\
\text { family*** }\end{array}$} & below mean & $67.80 * *$ & $63.03 * * *$ & $58.06^{* *}$ & $68.37 *$ \\
\hline & above mean & $74.93 * *$ & $73.31 * *$ & $66.99 * *$ & $81.15^{*}$ \\
\hline
\end{tabular}

Source: IESA 2015

During the examination of the students, an important dimension of the analysis was the choice of school institution in previous years, because the manner in which students can utilize the knowledge, values and norms gained during high school may differ. The significance of which school is chosen is even greater in a minority community. In addition, instruction in a mother tongue serves the long-term operation of such communities (Papp Z., 2012). It is a proven fact that the students who study in their mother tongue have better results than those who choose schools where the language of the majority is spoken (Papp Z., 2013). The information from the database pertaining to high school studies also is at our disposal. Furthermore, beyond the students' school choice behavioral patterns, we can also infer their ambitions to study further and their families' readiness to sacrifice, when we see that families in every region feel the need for their children to take part in paid private classes (Pusztai \& Márkus, 2019). Our results show that in Romanian students' case participation in private classes did not support the formation of persistence, and the students that were present, who didn't take part in this form of shadow education, had a far more significant persistence value (73.55).

It has already been mentioned that in the moderation of dropout institutional socialization processes play a crucial role. The literature on the subject ties the success of these processes to the forming and sustaining of increasingly frequent and complex patterns of relationship networks (Pusztai, 2018, 2011). In our tests we differentiated the inter- and intragenerational personal and intellectual contacts, that is we made a difference between relationships maintained between teammates, classmates, and teachers. We qualified personal relationship as, when a student talks about things from his/her personal life, he/she spends his/her free time with the instructor or a fellow student, or personally seeks out that person either on the phone or by visiting his/her home. We categorized as intellectual those conversations when students talk about studies, academic questions, professional future plans, personal and cultural topics, and also those occasions when they study together or exchange notes. We related students' average values to each other, comparing the above and below average (mean) values with persistence numbers. Based on our results, it appears that in Romania there is no statistically measurable relationship between the variables. In Ukraine and Slovakia the intergenerational personal contacts support perseverance and the chance at successful diploma acquisition. Those students who were above mean in 
personal contact with their teachers, in both regions, achieved much higher persistence numbers, in Ukraine 67.20, while in Slovakia 64.30 (in contrast to the other student groups' values - 61.78 and 58.03).

In Ukraine, the relationships formed and maintained with teachers continued to increase the odds of persistence development. A result worthy of mention, however, is that those Serbian students who reported less than average intragenerational personal relationships received higher persistence scores ( 81.92 vs. 69.28). Thus, it seems in this case, these relationships draw attention away from studies rather than directing the latter to them.

Educational research considers the following to be an important question: In what space and community circles do students move during their years at university? Our previous tests have proven that there are multitudes of differences between the commuting and dorm-dwelling students. For instance, among dorm-dwelling students drop-out is much lower, they're more contented with their institutions, they more often plan to continue their studies, and they more actively take part in extracurricular activities (Pusztai, 2011). Our results show that the dorm students of Transcarpathia truly enjoy a significant advantage (69.27) in the process of becoming persistent, whereas among the other regions' students we could find no significant connection between the variables. The reason for this is presumably that most students dwelling in dormitories are Ukrainian (followed by the dorm students of Slovakia, Romania, and lastly Serbia). The high ratio of Transcarpathian students in dorms explains the fact that, due to the low numbers of institutions in operation here, some faculties and majors have a wider area of attraction than in other regions. For rural or countryside student communities having access to a dormitory is of great importance, and from this perspective Serbian and Slovakian Hungarians are in a worse than unfavorable situation. In Transcarpathian students' cases, the various memberships increase greatly the odds of developing persistence. Those students who displayed above average membership achieved far higher persistence scores (67.98 in contrast to 59.14).

At last, we compared in a control analysis the unified effect of the above detailed variables with the odds of becoming persistent, and we made estimates of the expected values of each variable in this way. We dichotomized the previously examined (spanning from 0 to 100) persistence main component weights compared to the average. Our goal with setting up the logistical regression model was to test, to see, if the already examined explanatory variables influence the odds of becoming persistent, or not. Without a doubt, other variables than the incorporated explanatory variables are capable of influencing our dependent variable, but, in this present case, our goal is the verification or rebuttal of the casual relationship itself, not the complete explanation. 
Table 2. The effect of individual and institutional embeddedness attributes on student persistence

\begin{tabular}{cccc}
\hline & $\mathbf{E x p}(\mathbf{B})$ & $\mathbf{E x p}(\mathbf{B})$ & $\operatorname{Exp}(\mathbf{B})$ \\
\hline Gender (0- female, 1-male) & $0.724^{*}$ & $0.714^{*}$ & $0.725^{*}$ \\
\hline Objective financial situation (0 - below mean, 1-above mean) & $0.755^{*}$ & $0.765^{*}$ & $0.757^{*}$ \\
\hline Subjective financial situation (0 - below mean, 1-above mean) & 0.906 & 0.921 & 0.916 \\
\hline Relative financial situation (0 - below mean, 1-above mean) & 1.106 & 1.115 & 1.101 \\
\hline Settlement type of residence at age 14 (0 - village, ranch, 1 -city) & 1.263 & $1.29^{*}$ & $1.306^{*}$ \\
\hline Social capital within the family (0 - below mean, 1-above mean) & $1.821^{* * *}$ & $1.842^{* * *}$ & $1.807^{* * *}$ \\
\hline Birth father school degree (0-without diploma, 1-with diploma) & 1.077 & 1.072 & 1.083 \\
\hline Birth mother school degree (0-without diploma, 1-with diploma) & 1.003 & 1.005 & 0.993 \\
\hline Romania (0- no, 1-yes) & $0.818^{* * *}$ & 0.838 & 0.798 \\
\hline Ukraine (0- no, 1-yes) & $0.477^{* * *}$ & $0.389^{* * *}$ & $0.35^{* * *}$ \\
\hline Slovakia (0- no, 1-yes) & $0.306^{* * *}$ & $0.292^{* * *}$ & $0.293^{* * *}$ \\
\hline participate) & & 0.866 & 0.857 \\
\hline Participation in private class (0 - didn't participate, 1 - did & & 0.842 & 0.851 \\
\hline High school caretaker (0 - state, 1 - church, private, foundation) & & 0.958 & 0.963 \\
\hline Hesidence during school year (0 - not dorm, 1 - dorm) & & 0.988 \\
\hline Membership (0 - below mean, 1-above mean) & & 0.921 \\
\hline
\end{tabular}

Rate of intergenerational intellectual contacts $(0$ - below mean, 1 -above mean)

Rate of intergenerational personal contacts $(0-$ below mean, 1-above mean)

Rate of intergenerational intellectual contacts $(0$ - below mean, 1-above mean)

Rate of intergenerational personal contacts $(0$ - below mean, 1-above mean)

Source: IESA 2015

We drew the variable groups into our logistical regression model in three steps - first the social background indicators, second the attributes of previous courses of study, and third the institutional effect indicator variables. We found that girls were more persistent than boys, and in their effect was consistent in each of the three models. In explanation, first, the effect of social expectations and family norms could be mentioned more often, but also the greater tendency to make contact could be behind this. However, the more advantageous economic status negatively affects the odds of developing persistence. Objective financial situation indicators showed negatively significant ties with persistence, thus financial wellbeing rather moderates than supports the transformation of a student to persevering. On the contrary, living in the city stands as a strong supportive factor. The size of social capital within the family, that is to say the strength of the relationship with the parents bears strong, positively-influential power. Its effect overrides every other status indicator, even when every other variable is draw in. Of the institutional relationship network indicators, though, the frequent intergenerational personal contacts alone support the odds of becoming persistent.

\section{Conclusions}

In our study, we contributed to the examination of drop-out among minority Hungarian higher education students. In our testing, we sought to send the research in the direction that focuses on the predictive factors and discusses the chances of persistence. Our goal was to identify, from among individual and institutional factors, those which increase chances of successful diploma acquisition. The examined results in a logistical regression 
model were placed all at once on the scale, that we might see which is most permanent. We dichotomized the persistence indicator measured with a 9-item Likert scale comparing it to the average, and, from region to region, we dealt with the explanation of becoming persistent above average. The results show that in every minority community women are more enduring and dedicated to getting a diploma. The more advantageous economic status counters it rather than assisting, yet living in a city significantly builds up the chances that persistence will develop. It seems that experience of the more widespread educational, cultural, even workforce opportunities offered by cities is clearly a great motivation to successfully get a diploma. However, among the relationship network samples, the student-teacher personal contact has a truly strong, also statistically relevant effect. Thus, our results allow us to deduce that in the practice of institution direction and organization, it's worth considering the reinforcement of teacher-student mentor systems. Beyond this though, it would also be worthwhile to dedicate attention to maintaining relationships with parents, after all, the system of values and norms conveyed by the family boast the strongest positive effect of all factors, thus propelling minority students to successful diploma acquisition. It would therefore be important to adapt the good practices of strengthening parent-institution relationships won from international literature on the subject in these institutions as well.

Funding: Project no. 123847 has been implemented with the support provided by the National Research, Development and Innovation Fund of Hungary, financed by the K_17 grant program.

Acknowledgments: I would like to express my gratitude to professor Gabriella Pusztai, my supervisor and mentor like no other. This paper and them research behind it would not have been possible to complete without her exceptional support, knowledge and attention. I also thank my colleagues from Center for Higher Educational Research and Development (CHERD) who were competent and devoted partners in the process of conceptualization and methodology.

Conflicts of Interest: "The funders had no role in the design of the study; in the collection, analyses, or interpretation of data; in the writing of the manuscript, or in the decision to publish the results".

\section{References}

Altbach, P. G. (2009). Introduction. In R. B. Ludeman, K. J. Osfield, E. I. Hidalgo, D. Oste \& H. S. Wang (Eds.), Student affairs and services in higher education: Global foundations, issues and best practices (pp. xiii-xiv). International Association of Student Affairs and Services (IASAS).

Astin, A. W.(1993). What matters in college: four critical years revisited. Jossey-Bass.

Márkus, Zs. (2015). A kisebbségi hallgatók tanulmányi elkötelezettsége. In G. Pusztai \& K. Kovács (Eds.), Ki eredményes a felsőoktatásban (pp. 172-182). Partium-PPS-Új Mandátum Könyvkiadó

Papp, Z. A. (2012). Az iskolaválasztás motivációi és kisebbségi perspektívái. Kisebbségkutatás, 21(3), 399-417.

Papp, Z. A. (2013). Többségi nyelvü iskolaválasztás kisebbségben, avagy a PISA-adatoktól a Kárpát-medencei diskurzusokig. Kisebbségkutatás, 22(4), 7-17.

Pascarella, E. T., \& Terenzini, P. T. (1980). Predicting freshman persistence and voluntary dropout decisions from a theoretical model. The journal of higher education, 51(1), 60-75.

Pusztai, G. \& Verdes, E. (2002). A társadalmi tőke hatása a felekezeti gimnazisták továbbtanulási terveire. Szociológiai Szemle, 12(1), 89-105.

Pusztai, G. (2004). Iskola és közösség: felekezeti középiskolások az ezredfordulón. Gondolat.

Pusztai, G. (2009). A társadalmi tőke és az iskola. Új Mandátum Könyvkiadó.

Pusztai, G. (2011). A láthatatlan kéztől a baráti kezekig: Hallgatói értelmezö közösségek a felsőoktatásban. Új Mandátum Könyvkiadó.

Pusztai, G. (2014). Variációk felsőoktatási környezetre. Kísérlet az intézményi környezet hallgatói eredményességre gyakorolt hatásának vizsgálatára. Felsőoktatási Mühely, 8(3), 67-90.

Pusztai, G., \& Ceglédi, T. (2015a). Professional Calling in Higher Education: Challenges of Teacher Education in the Carpathian Basin. Personal Problems Solution, Új mandátum Könyvkiadó.

Pusztai, G., \& Kovács, K. (2015b). Ki eredményes a felsőoktatásban? Partium-PPS-Új Mandátum Könyvkiadó.

Pusztai, G. (2018). Egy hatekony tenyező a lemorzsolódás mérséklésére. In G. Pusztai \& F. Szigeti (Eds.), Lemorzsolódás és perzisztencia a felsőoktatásban (pp. 109-127). Debrecen University Press.

Pusztai, G., \& Szigeti, F. (Eds.). (2018). Lemorzsolódás és perzisztencia a felsőoktatásban. Debrecen University Press.

Pusztai, G., \& Márkus, Zs. (2019). Paradox of assimilation among indigenous higher education students in four central European countries. Diaspora, Indigenous, and Minority Education, 13(4), 201-216. 
Pusztai, G., Bocsi, V., \& Ceglédi, T. (2016). A felsőoktatás hozzáadott értéke közép-európai kontextusban. In G. Pusztai, V. Bocsi \& T. Ceglédi (Eds.), A felsőoktatás (hozzáadott) értéke: Közelitések az intézményi hozzájárulás empirikus megragadásához (pp. 7-12). Partium-PPS-Új Mandátum Könyvkiadó.

Tinto, V. (1975). Dropout from higher education: A theoretical synthesis of recent research. Review of educational research, 45(1), 89-125.

(ब) (1)

(C) 2020 by the authors. Submitted for possible open access publication under the terms and conditions of the Creative Commons Attribution (CC BY) license (http://creativecommons.org/licenses/by/4.0/). 